
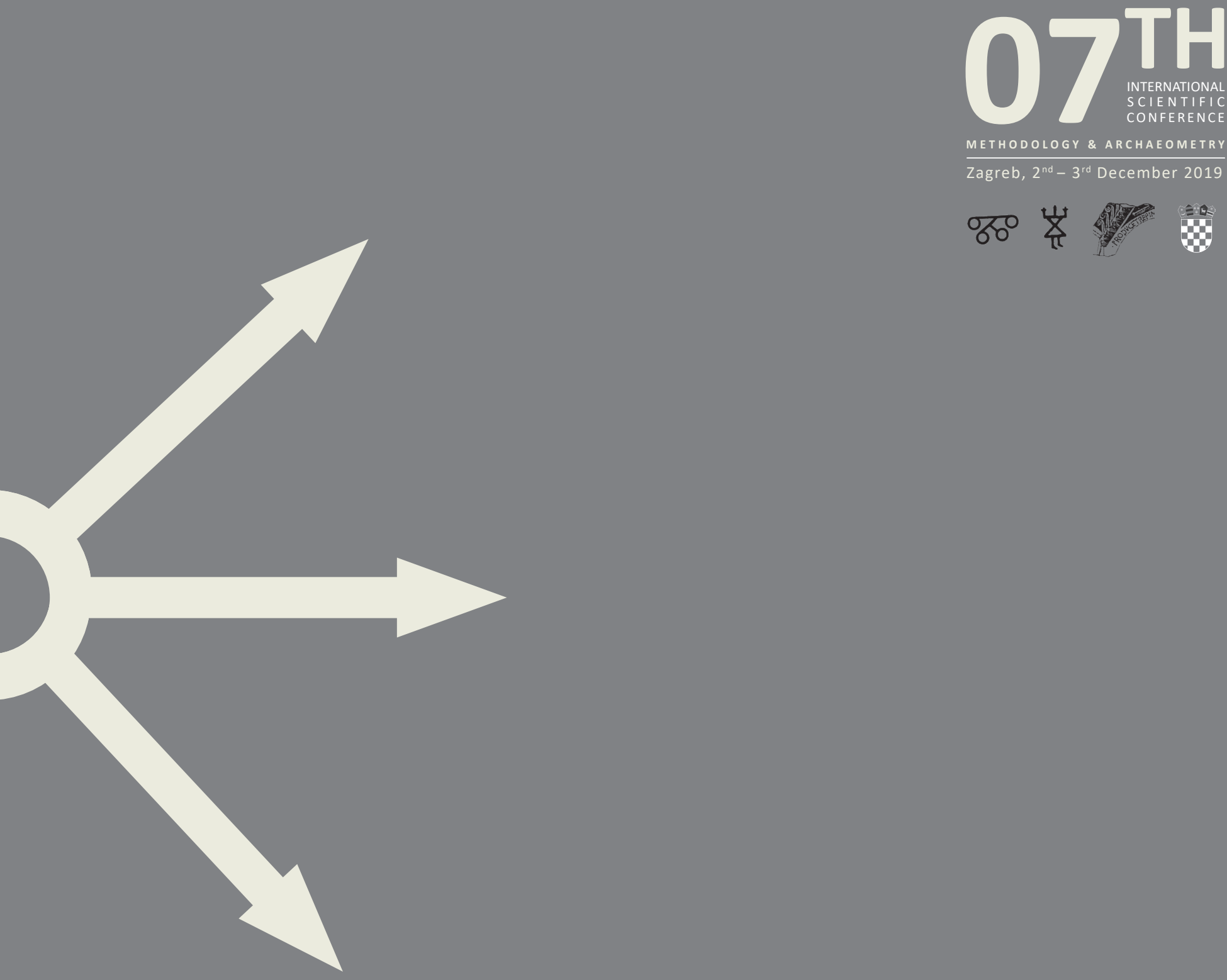
\%ㅇㅇ 岗

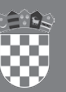
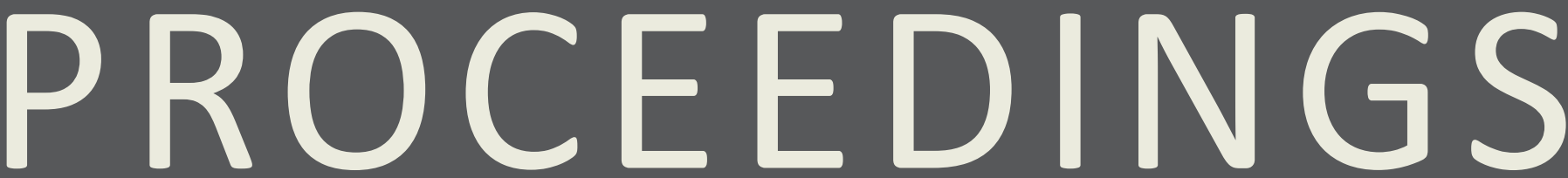

FROM THE $7^{\text {TH }}$ SCIENTIFIC CONFERENCE METHODOLOGY AND ARCHAEOMETRY 


\section{IMPRESSUM}

PUBLISHER

Faculty of Humanities and Social Sciences, University of Zagreb

FOR THE PUBLISHER

Miljenko Šimpraga

EDITOR

Ina Miloglav

Faculty of Humanities and Social Sciences, University of Zagreb

EDITORIAL BOARD

Predrag Novaković

Faculty of Arts, University of Ljubljana, Slovenia

Dimitrij Mlekuž

Faculty of Arts, University of Ljubljana

\& Centre for preventive archaeology, Ljubljana, Slovenia

Michela Spataro

The British Museum, London, United Kingdom

Duska Urem-Kotsou

Democritus University of Thrace, Komotini, Greece

Jasna Vuković

Faculty of Philosophy, University of Belgrade, Serbia

Rajna Šošić Klindžić

Faculty of Humanities and Social Sciences, University of Zagreb, Croatia

Jacqueline Balen

Archaeological Museum in Zagreb, Croatia

DESIGN \& DTP

Srećko Škrinjarić

All papers were reviewed in the peer review process in which the identity of both reviewers and authors, as well as their institutions, are respectfully concealed from both parties.

DOI

https://doi.org/10.17234/METARH.2020

ISSN 2718-2916

Faculty of Humanities and Social Sciences of the University of Zagreb

URL

https://openbooks.ffzg.unizg.hr/index.php/FFpress/catalog/series/MetArh http://www.ffzg.unizg.hr/metarh/

Publishing of this e-book is supported by

Ministry of Science and Education of the Republic of Croatia any medium or format, as long as they give appropriate credit, provide a link to the license, and indicate if changes were made. The content of this publication may not be used for commercial purposes. If the publication is remixed, transformed, or built 

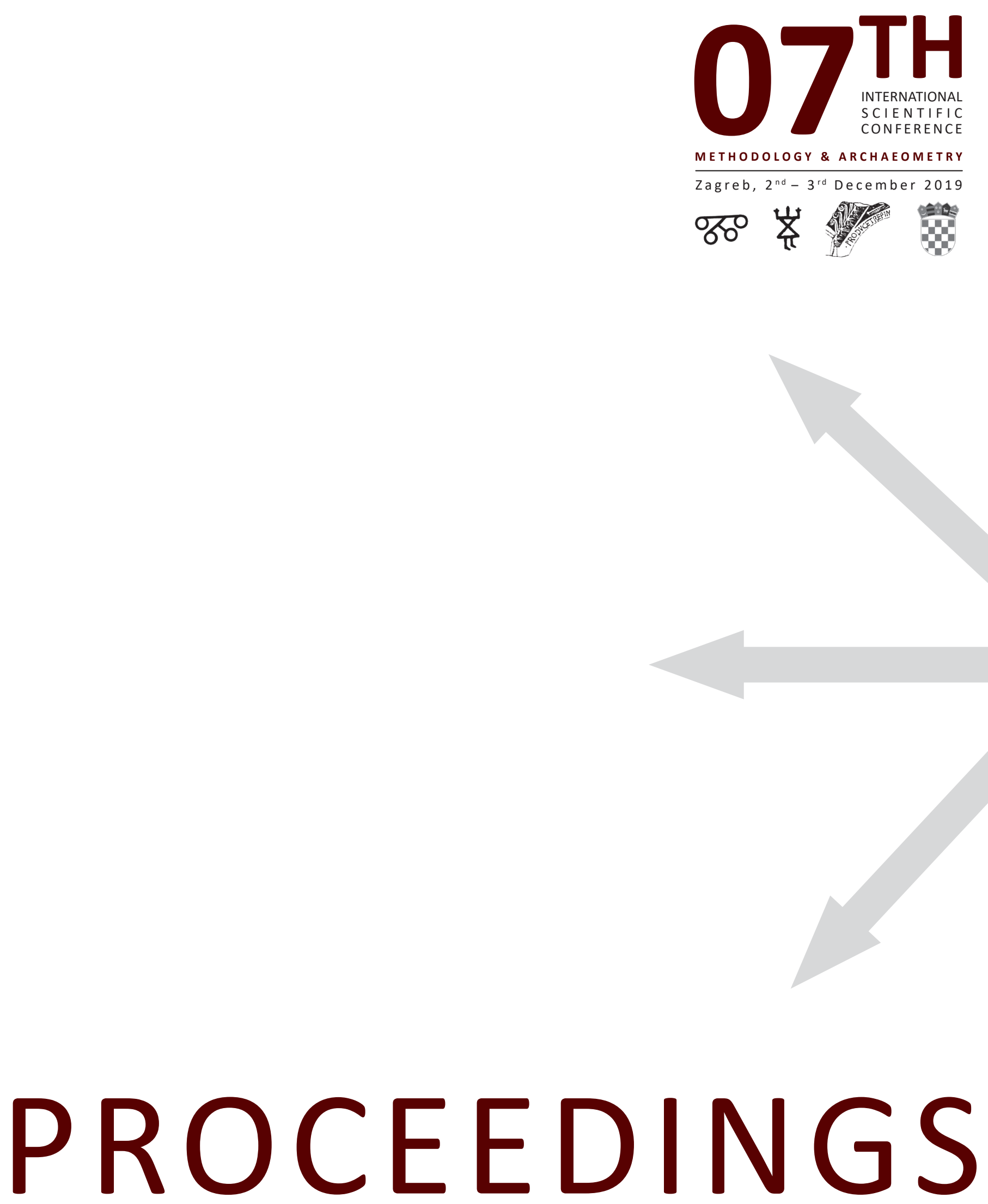

FROM THE $7^{\text {TH }}$ SCIENTIFIC CONFERENCE METHODOLOGY AND ARCHAEOMETRY 


\section{Content}

Ina Miloglav

Preface

Tamara Leskovar

09 Laboratory-based research on the changes caused to the in situ preserved archaeological remains by the heavy equipment compaction

Cornelius Meyer, Saša Kovačević, Daria Ložniak Dizdar, Mario Gavranović, Rajna Šošić-Klindžić, Tomislav Hršak, Marko Dizdar, Hrvoje Vulić, Boris Kratofil

Patterns everywhere: Geophysical prospection strategies at archaeological sites in Northern and Eastern Croatia

Domagoj Tončinić, Vinka Matijević, Miroslav Vuković

Image-based modeling approach in documenting Early Christian memorial chapel in Velić, Croatia

Esmeralda Agolli

A discussion on the theoretical and methodological ramifications of classification and typology of archaeological material: a Perspective from the Late Prehistoric Pottery (Albania)

Katarina Šprem

All aboard! Quarries and transport in Roman Istria 


\title{
Image-based modeling approach in documenting Early Christian memorial chapel in Velić, Croatia
}

\author{
Domagoj Tončinić, Vinka Matijević, Miroslav Vuković
}

https://doi.org/10.17234/METARH.2020.04

\author{
Domagoj Tončinić \\ Vinka Matijević \\ Miroslav Vuković \\ University of Zagreb \\ Faculty of Humanities and Social Sciences \\ Department of Archaeology \\ Ivana Lučića 3 \\ HR - 10000 Zagreb \\ dtoncinic@ffzg.hr \\ vibubic@ffzg.hr \\ mivukovic@ffzg.hr
}

Systematic archaeological excavations in the Velić village, near Trilj, began in 2013. By 2019 we revealed the remains of a rectangular ground plan building with a semicircular apse. It consists of the antechamber and three chambers: central chamber with an apse, south chamber, and north chamber with an east-west oriented barrel-vaulted tomb (Tomb 1), which was unfortunately quite devastated. In addition to this devastation, excavation campaigns have been characterized by the extreme poverty of small finds, which prevents accurate dating of the site. Nevertheless, the building can be roughly dated to the period of Late Antiquity and interpreted as an Early Christian memorial chapel. This assumption was reinforced in the 2019 excavation campaign when another barrel-vaulted tomb (Tomb 2) was detected below the central chamber with an apse. This time it was sealed and intact. It had a small square antechamber with a vertical stone slab serving as a door to the tomb. Its barrel-vaulted ceiling was completely preserved, and skeletal remains of four individuals were identified laying down on two flat stone plastered beds in the grave chamber.

Although the tomb and its state of preservation were astonishing, the archaeological excavation faced a daunting task of documenting the buried structure and its content. Since image-based modeling has been used as a practical and detailed documentation tool on the site so far, it was only natural to approach this part of the excavation in the same manner. This paper will present difficulties and solutions that we came across during the documentation process of this barrel-vaulted tomb as well as some conclusions and interpretations of the tomb and the larger complex around it.

Keywords: Velić, Early Christian memorial chapel, barrel-vaulted tomb, archaeological documentation, image-based modeling, photogrammetric 3D models

\section{Introduction, context, site}

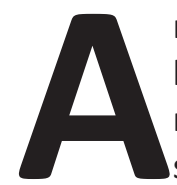
rchaeological site discussed in this paper is located in the area of the Velic village, $6 \mathrm{~km}$ northeast of Trilj, along the north side of the state road connecting Trilj and Livno in Bosnia and Herzegovina. The site, situated on a plateau overgrown with young forest and low vegetation, remained unknown until 2011 after which it undergoes archaeological surface survey on several occasions and, from 2013, systematic archaeological excavations with the conservation of the discovered architecture (Tončinić and Demicheli 2013; Tončinić et al. 2014; 2015; Bubić 2015; Tončinić et al. 2016; 2017; 2018; 2019). In addition 


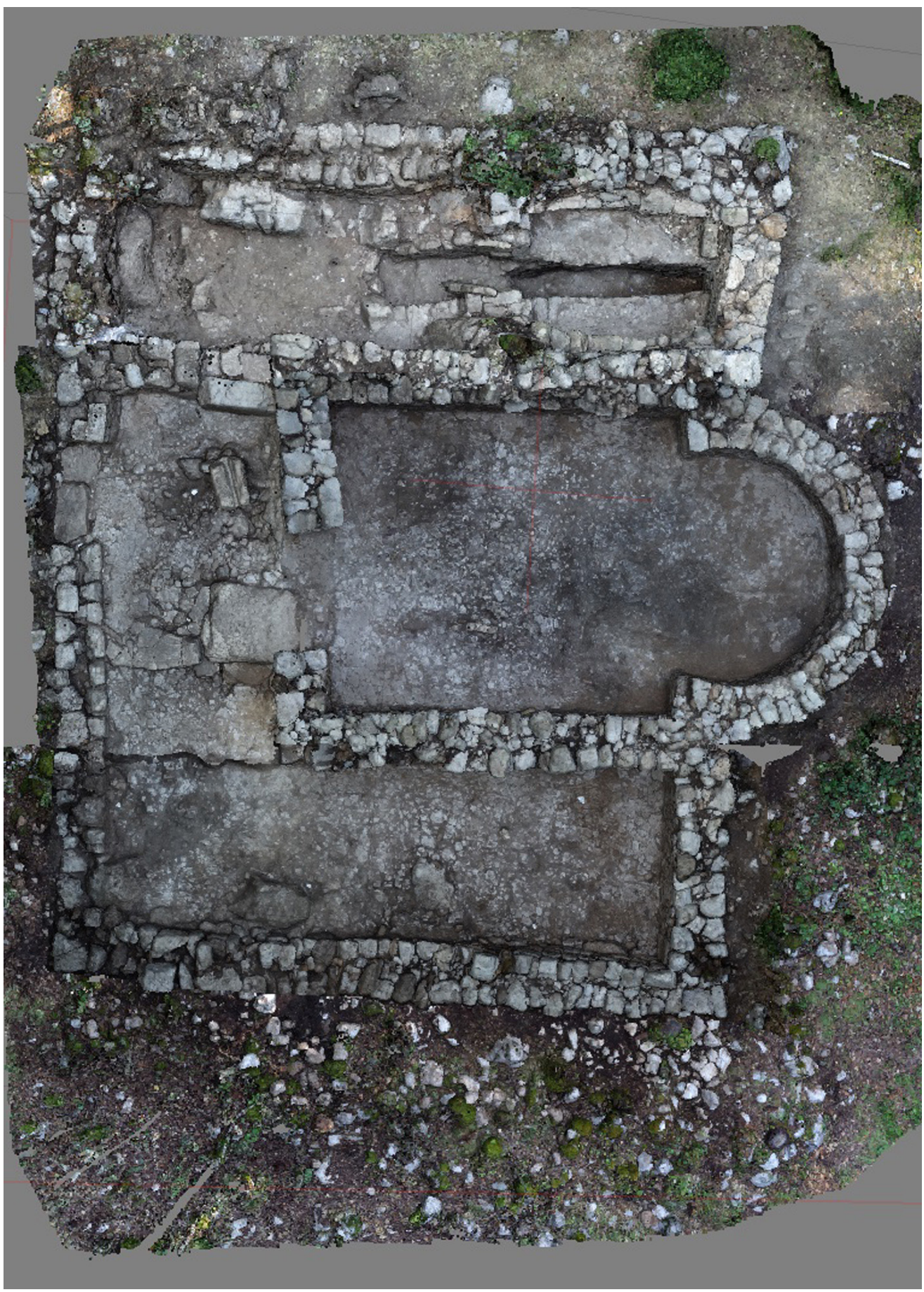

Figure 1. Remains of a rectangular building with an apse located in the vicinity of Velić (Archive of the Velić project, VEL19-003, made by: M. Vuković).

to this research, in 2014 a student project was launched with the aim of mapping the surrounding structures currently visible in the landscape. Today, this project also encompasses the creation of a 3D model of the site as well as the mapping of historical road communications in the wider area (Bužanić et al. 2017; 2018; Tončinić 2020: 375-378).
To this day we have excavated, documented, and preserved the remains of a rectangular ground plan building (dims. $8.46 \times 10.52 \mathrm{~m}$ ) with a semicircular apse $(2.74 \mathrm{~m}$ wide and $1.92 \mathrm{~m}$ deep) (Fig. 1). The structure is oriented east-west, with a slight deviation towards the southeast. It consists of a smaller rectangular antechamber and three chambers of different sizes and shapes: central 
Figure 2: Colored display of chambers and tombs within the excavated building (Archive of the Velić project, made by: $M$. Vuković).

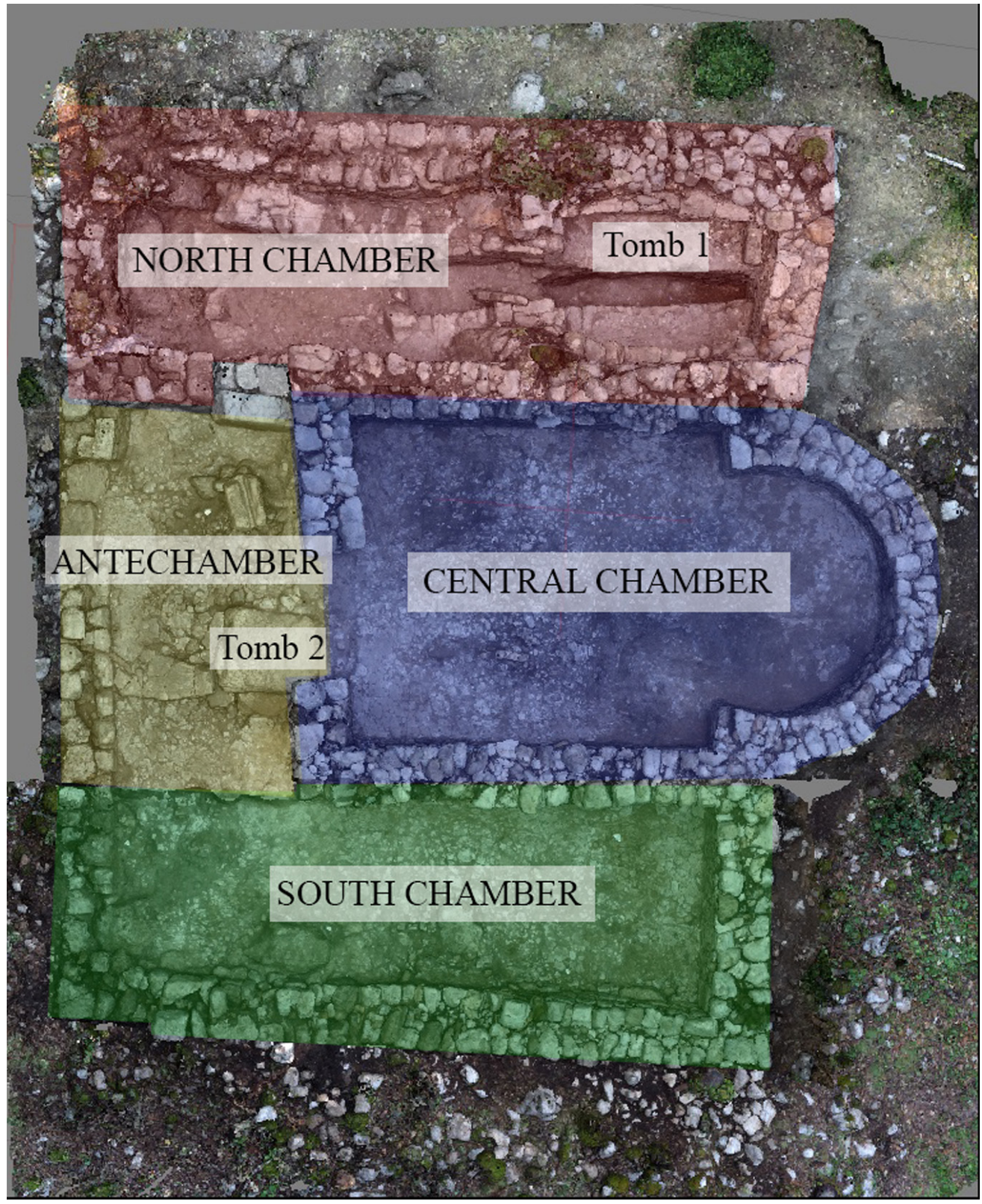

chamber with an apse at its eastern end, south chamber, and north chamber that contains a barrel-vaulted tomb (Tomb 1) (Fig. 2). The building has a plastered floor (Tončinić 2020: 372).

The entrance to the antechamber (dims. $6.70 \times 2.20 \mathrm{~m}$ ) of the object is located on the west and defined by a threshold consisting of two stone slabs of different dimensions. The central part of the structure occupies the largest chamber (internal dims. $3.75 \times 4.35 \mathrm{~m}$ ) with its entrance to the west, from the antechamber, and the aforementioned apse to the east. The south chamber (internal dims. $8.46 \times 3.40 \mathrm{~m}$ ) is entered directly from the antechamber, without any visible threshold, doors, partition walls or denivelation, while at the north end of the antechamber lies a stone threshold used to descend into the north chamber (internal dims. $7.86 \times 2.17 \mathrm{~m}$ ). Its walking surface is on a somewhat lower level than a walking surface of the antechamber, the central, and the south chamber, and its walls are partially laid on the bedrock. In the east part of the north chamber, there is a stone barrel-vaulted tomb. 
The object is roughly dated to the period of Late Antiquity and interpreted as an Early Christian memorial chapel (Tončinić 2020: 375). A small number of small finds was recorded during the archaeological research; it is mostly consisted of a greater number of amorphous pottery, several fragments of utility ware and poorly preserved metal findings. For now, the only indication for determining the date comes from poorly preserved mid $-4^{\text {th }}$ century coin discovered at the entrance to the tomb in the north chamber. The possibility that the coin was originally a grave good which reached the site of the discovery during the devastation of the tomb is not excluded. However, bearing the context of the discovery in mind, it is more probable that it reached the site before the time of the erection of the memorial chapel, and that the time of minting, between 348 and 361 AD, represents terminus ante quem non for construction (Tončinić 2020: 374).

\section{Tomb 1}

The aforementioned barrel-vaulted tomb (dims. $9.04 \times$ $3.32 \mathrm{~m}$ ), whose discovery in 2011 was the reason behind the surface survey and the preservation of this archaeological site, has a square entrance to the west. Originally, it was sealed with the vertically placed stone slab which was found in its proximity. Stairs, partially embedded into bedrock, were used to descend into the burial chamber (Tončinić 2020: 372-373). The barrel vault made of properly hewn slabs of "muljika" (soft local limestone) has not been preserved; however, the east wall of the tomb follows the shape of an arch, with traces of plaster that have been documented (Fig. 3). Therefore, it is highly likely that the vault was made of "muljika" stone slabs vertically stacked next to each other and joined with plaster - in a similar fashion to other vaulted tombs (see: Bubić 2016: 23-25, 53, 62, 126, 129). Inside the tomb, along its north and south walls, are stone plastered beds

Figure 3. East wall of the Tomb 1 (Archive of the Velić project, VEL13-dig0202, author: D. Tončinić).

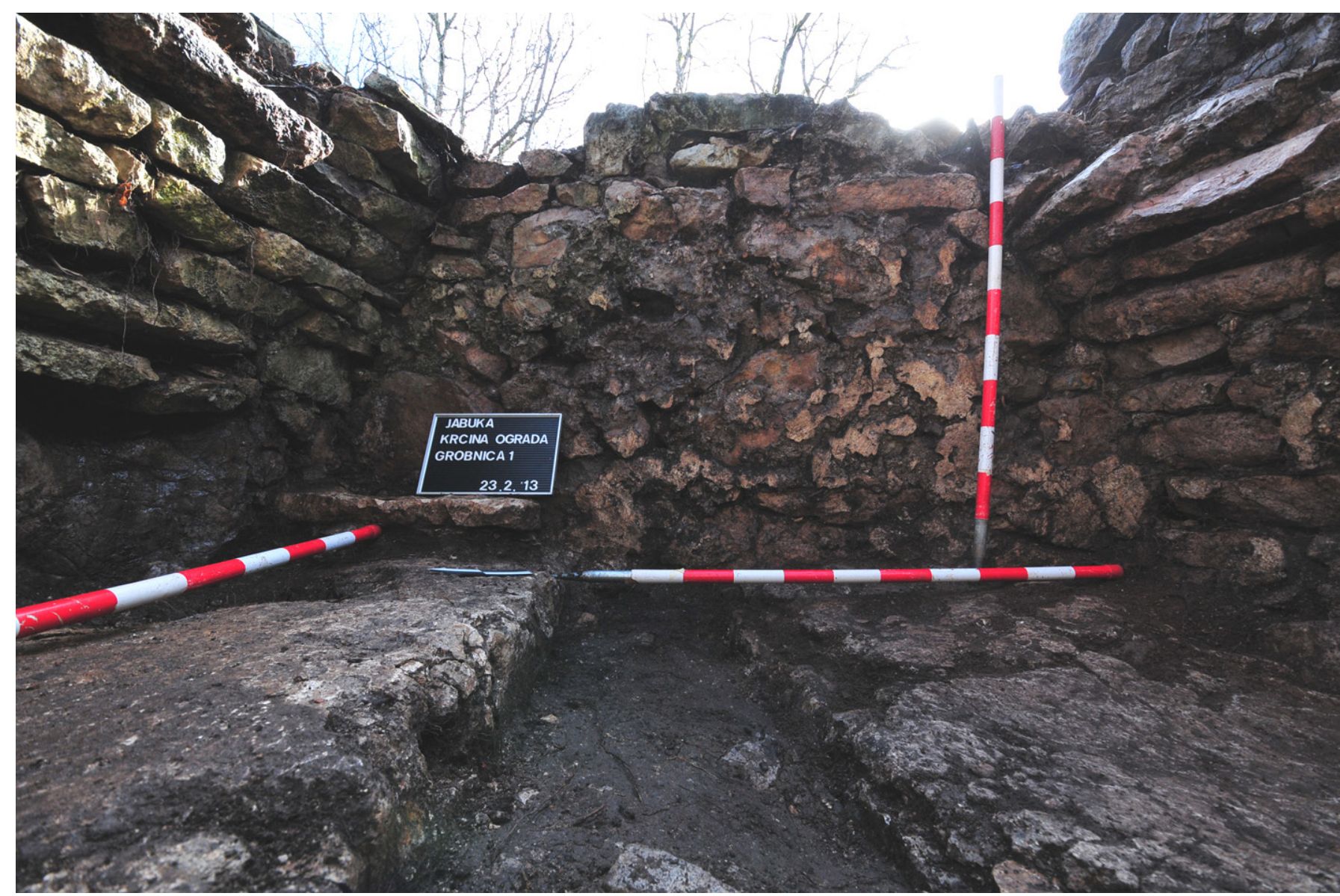




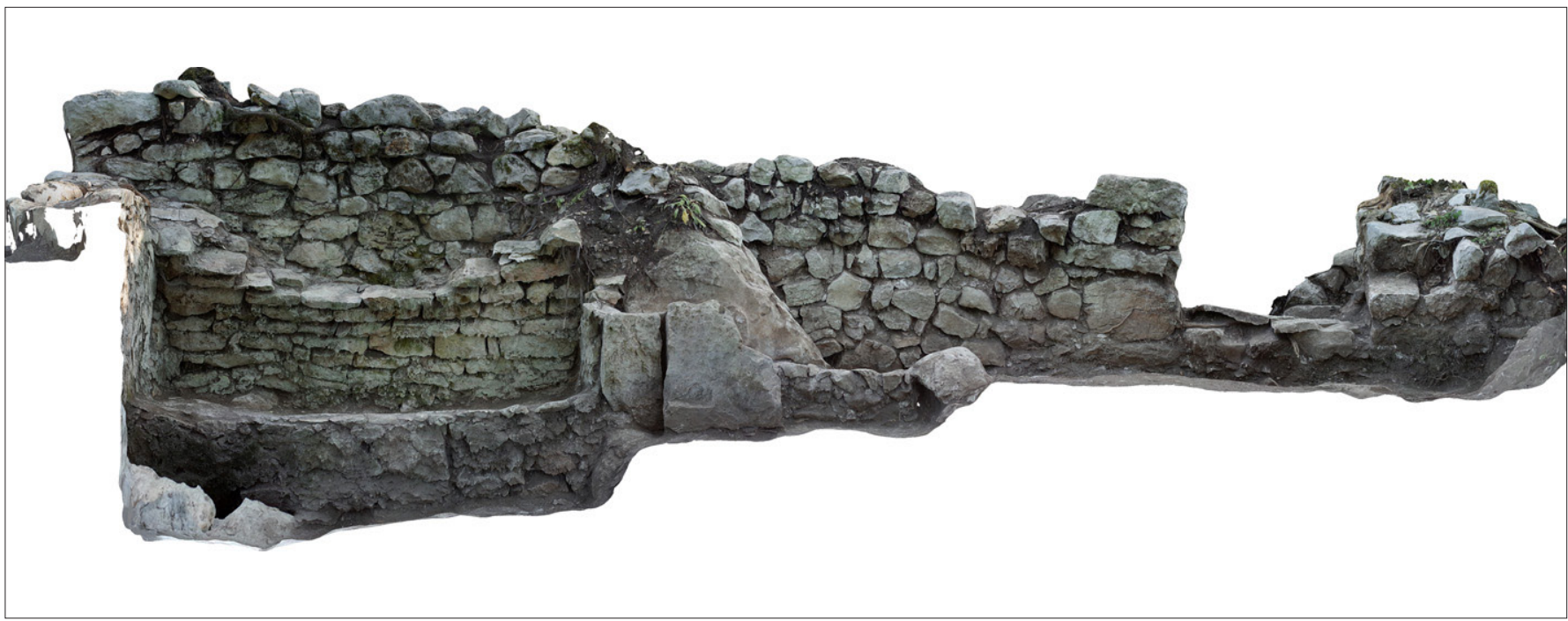

Figure 4. Cross-section of the Tomb 1, view looking south tomb wall (Archive of the Velić project, made by: M. Vuković).

that serve to lay the deceased, with a narrow channellike ossuary in between used for depositing skeletal remains. A skeleton was documented on the south bed, with its skull oriented to the east. Anthropological analysis has shown that it belongs to a male individual between the ages of 50 and 60 (Šlaus et al. 2013). Parts of the skeleton were documented in the ossuary as well as at the entrance to the tomb. This discovery, along with the fact that the doors of the tomb were found open, confirms that the tomb was devastated at a hitherto unknown period. The devastation was further evidenced by the scattered parts of skeletons in the central chamber with the apse, presumably belonging to a male and a female, both over the age of 40 (Šlaus et al. 2018).

\section{Documenting Tomb 1}

In a very early stage of systematic archaeological excavations, it was clear that documenting the site would prove to be a challenge due to the narrow shape of the discovered vaulted tomb. As the vaulted ceiling of the tomb has collapsed, the birds-eye perspective of the tomb was clear, but the sidewalls and the remains of the vault were hard to approach and document as there was not enough space inside the tomb to get a perspective wide enough for proper documentation of the walls. Additionally, there was a problem with measuring points with the total station as most of the tomb was obscured from the view of the measuring device due to the angle of view and the depth of the tomb compared to the local terrain. The mentioned factors necessitated the search for a documentation method different from what was the standard at that time for this type of excavations.

After short experimentations with laser scanning and image-based modeling, it became clear that the latter method would provide the necessary level of detail and precision. The efficiency of this method compared to laser scanning has already been proven on archaeological sites (Gonizzi Barsanti et al. 2012). The problem with the terrestrial laser scanner in this instance was similar to the problem that arose with the total station: when the scanner was placed outside of the tomb it did not capture all the points inside due to the unfavorable angle, and it was not possible to set the scanner inside the tomb. This problem could have perhaps been solved by using a hand-held scanner for measurements but at the time we didn't have access to such equipment. The image-based modeling approach, on the other hand, satisfied the documentation standards and was also a more cost-effective solution.

Due to the already mentioned features of the tomb, the plan for acquiring the images for the 3D model was complex and the resulting web of images covered the tomb itself from all possible angles. While acquiring the images it was important to consider the final goal, which was to gain a 3D record of the site which would enable the acquisition of all the necessary measurements as well as the necessary orthophoto plans for the technical drawings of the site. These include vertical perspective, side 


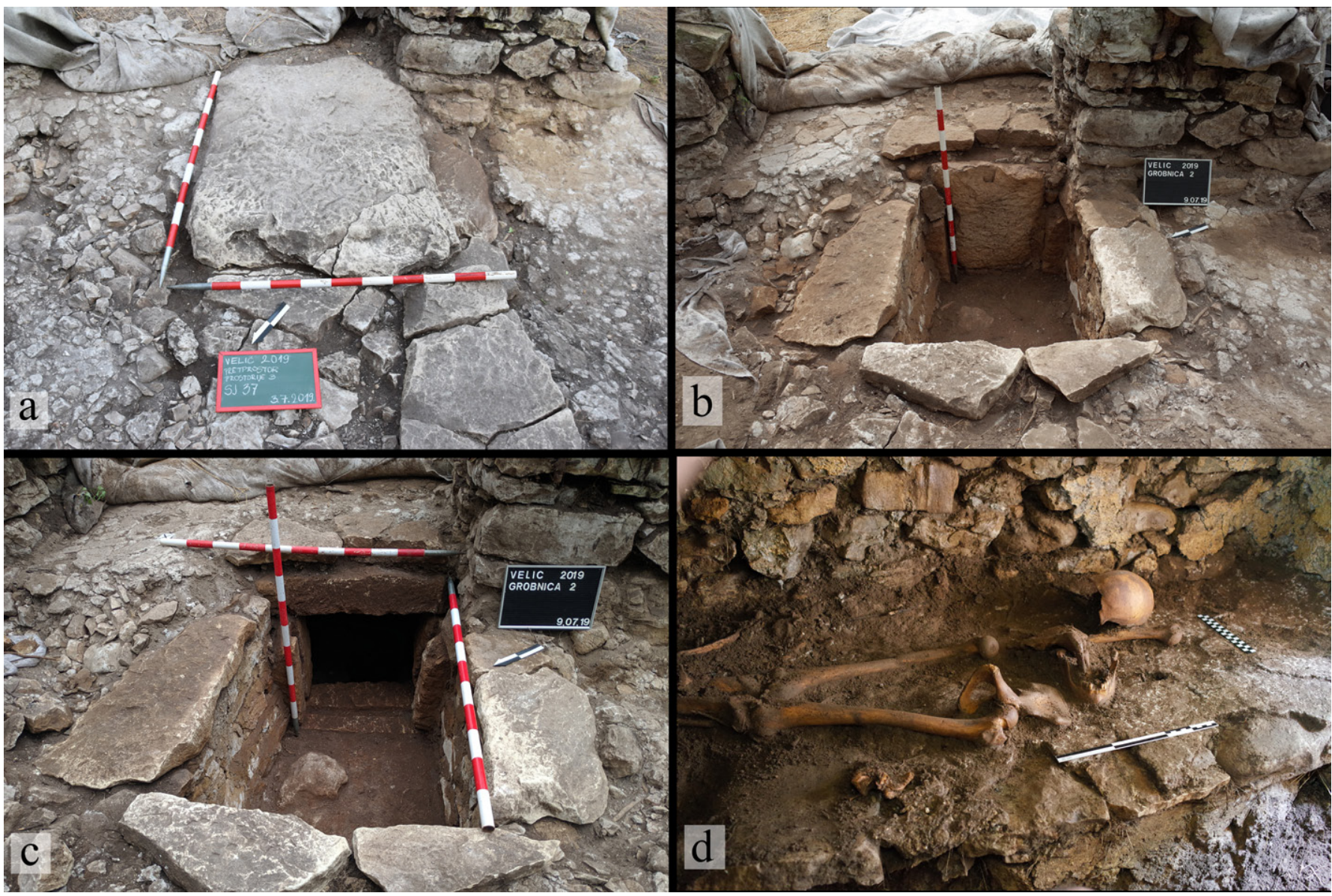

Figure 5. The discovery of Tomb 2 in phases - a) square "muljika" stone slab covering Tomb 2 (VEL19-dig005); b) Tomb 2 after the removal of the stone slab (VEL19-dig054); c) entrance to the burial chamber (VEL19-dig087); d) human osteological remains at the south bed (VEL19-dig101). Archive of the Velić project, authors: a) V. Matijević, b, c) D. Tončinić, d) M. Vuković.

perspectives, and cross-sections (Fig. 4). To achieve the best result, the images were taken vertically to the surface that was being recorded, so that the potential distortions on the orthophoto plans would be minimized.

\section{Documenting the tomb's surroundings}

The image-based modeling approach proved efficient, precise, and fast, so it was quickly implemented on other excavations as well as in the subsequent seasons on the Velić site. As the research progressed, the rectangular building surrounding the tomb began to take shape. As each segment of the building was explored, a detailed 3D model was created. The time spent on the site each year was limited, which is why the excavation of the building spanned over several seasons. Recognizing that this is not an archaeologically ideal situation, image-based modelling approach was accepted as the best solution. This allowed the team to combine the data from multiple seasons in order to get a clear view of the building, enabling the formation of a detailed technical plan of the structure. At the same time, it allowed the combination of the 3D model of the excavated building and the 3D model of the surrounding area (Bužanić et al. 2017; 2018; Tončinić 2020: 377, SI. 15).

\section{Tomb 2}

On the floor of the antechamber at the entrance to the central chamber of the building, a square "muljika" stone slab (dims. $1.20 \times 0.90 \mathrm{~m}$ ) was discovered in 2019 (Fig. 5a). Initially, it was considered to be a simple grave covered with a stone slab; however, lifting the large stone slab uncovered an entrance to a Tomb 2 with a 
small antechamber and large stone doors still in their original grooves (Fig. 5b-5c).

Tomb 2 has a rectangular ground plan (internal dims. $2.18 \times 1.72 \mathrm{~m}$ with an average height of $1.60 \mathrm{~m}$ ) and is oriented east-west, with the entrance located on its west side. The entrance contains a threshold; a tall stair which descends directly into an ossuary (average width of $0.45 \mathrm{~m}$ ), i.e., a space between two beds (cca. $0.60 \mathrm{~m}$ wide each). Barrel vault of the tomb is completely preserved. "Muljika" stone slabs, of which the vault is built, are placed in a similar fashion to those in the Tomb 1. Both of the beds, like the ossuary, contained human osteological remains (Fig. 5d). Anthropological analysis has shown that the remains belong to four deceased individuals: a younger male subject (18-25 years old) whose skeleton rested on the south bed while some bones were also found in the ossuary, and three children (aged: 9-11 years; 4.5-5.5 years; and 3-4 years) (Novak and Carić 2019). The bones of the first child were scattered on the north bed and in the ossuary. The second child was laid on the south bed, with the position opposite to the man's so its head was to the east, and the youngest child was also buried on the north bed, with some bones documented in the ossuary. The skeletons are not entirely preserved and were most likely disturbed by rodents whose remains were also documented in the tomb. There were no other archaeological findings recorded.

\section{Documenting Tomb 2}

The state of the tomb, together with the skeletal remains, was documented upon entry, and the second set of images was taken after the skeletons were cleared from the dirt. This approach enabled a clear picture of all three phases of exploring the tomb, and more importantly, provided data regarding the exact position of the skeletal remains inside the tomb.

After the human remains and the layers of the soil inside the tomb were removed, the structure was ready for the documentation process. The narrow entrance presented a problem not only during the excavations but also during the measuring of data on the site. By placing the total station at the correct angle outside the tomb (Fig. 6a) we were able to measure two ground control points (GCPs) inside the tomb, at the bottom of the ossuary situated between the two beds (Fig. 6b). Three additional GCPs were situated outside the tomb, in, and around the antechamber next to the entrance.

To acquire the necessary data, a RICOH GR II camera was used in combination with a monopod when needed, and an additional light source was mounted on a helmet because of the dark conditions inside the tomb.

The basis for a good and precise photogrammetric 3D model is image overlap; ideally, the overlap between the two images should be more than $80 \%$ (Agisoft LLC 2019). The problem with the overlap in this particular case lays

Figure 6. Documentation process - a) positioning of the total station regarding the tomb entrance (VEL19-digo128); b) ground control point (GCP) inside the tomb (VEL19-MV). Archive of the Velić project, authors: a) V. Matijević, b) M. Vuković.

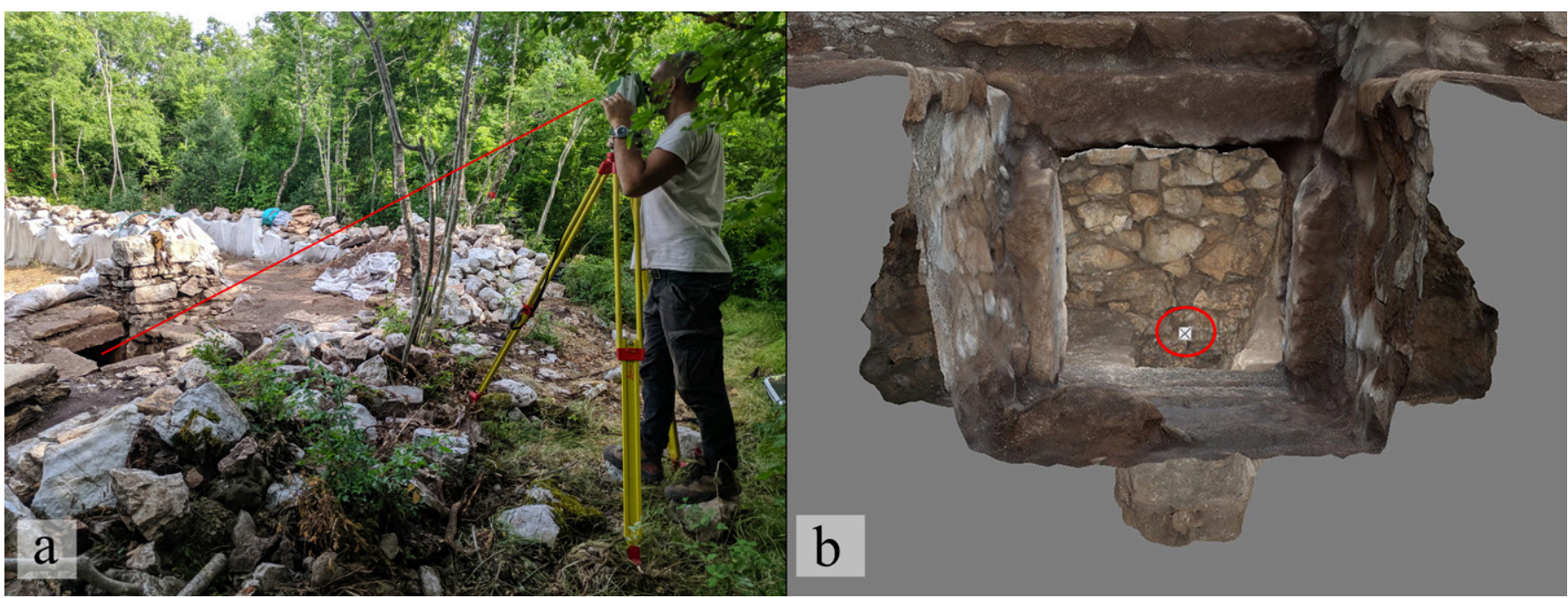


in the fact that the inside of the tomb was connected to the surface only by the narrow entrance, and that was the only connecting and overlapping area between the two perspectives (Fig. 7). To make sure that the precision of the model will be good enough for the extraction of the orthophoto views, additional relative measurements were taken with a measuring tape inside the tomb itself. This approach allowed for the creation of a 3D model of the inside of the tomb with accurate relative measurements, which can also be used for the creation of orthophoto plans. Nevertheless, the goal was to combine the data from the outside and the data from the inside so that, later on, this dataset could be combined with all the previous excavation seasons. The result was a complex pattern of recorded images, revolving mostly around the singular contact point at the antechamber and the entrance itself. It was important to cover the entrance from all possible angles as well as the inside of the tomb, including the bottom of the tomb, sidewalls, and the vaulted ceiling.
The finished and georeferenced 3D model covered all the necessary surfaces and included all the data needed for a precise orthophoto extraction (Fig. 8). The model was generated from a dense point cloud containing approximately 3 million points, and after georeferencing and bundle adjustment the resulting error in the data was $1.6 \mathrm{~cm}$. The precision of the data was additionally tested by overlapping extracted orthophoto views from a two separate 3D models: the one containing all the data and georeferenced by GCPs, and the one containing only the data from the inside of the tomb with relative referencing done by tape measurers. The conclusion of the test was that the difference between the two datasets is negligible (less than $2 \mathrm{~cm}$ ) for our documentation process.

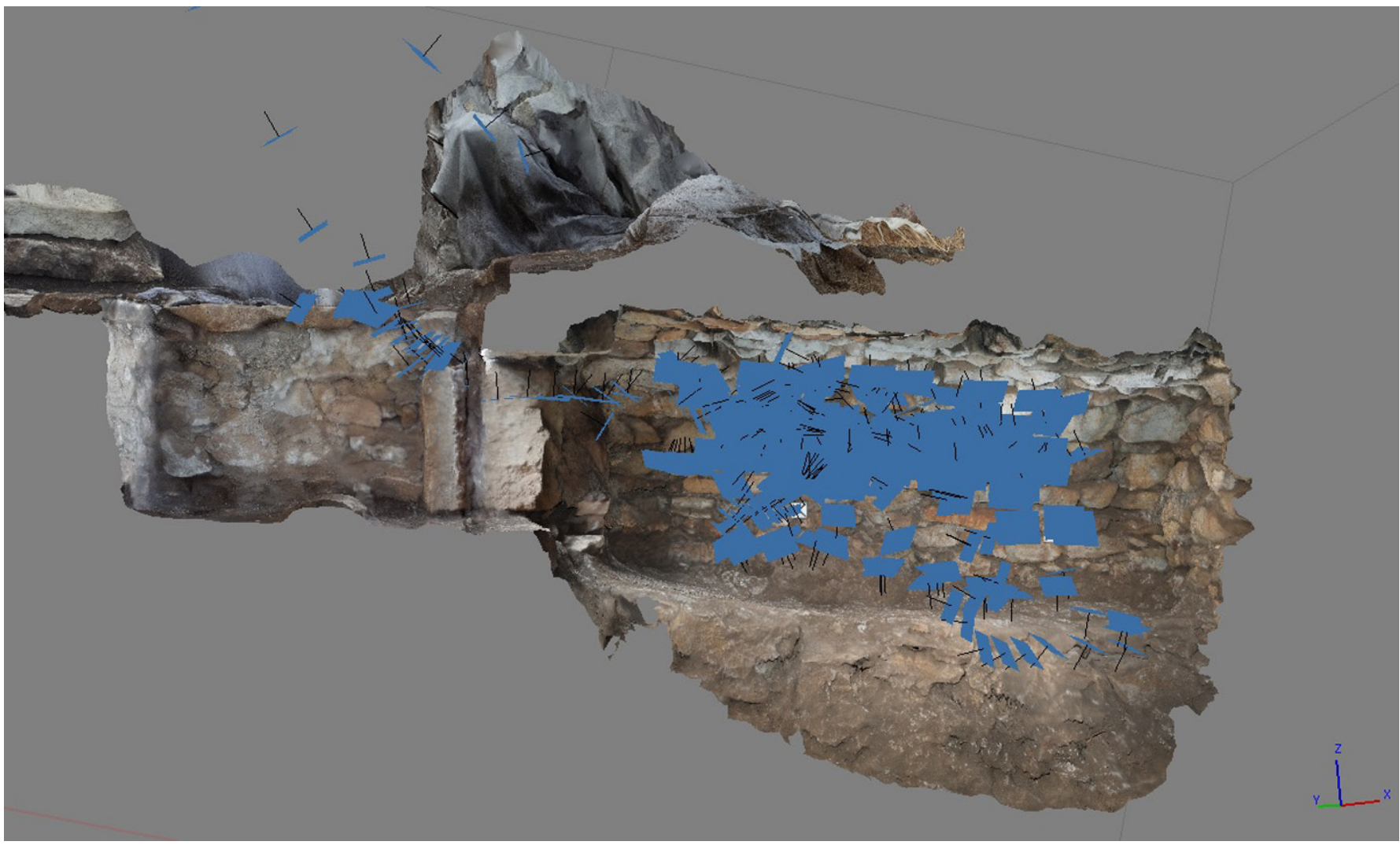




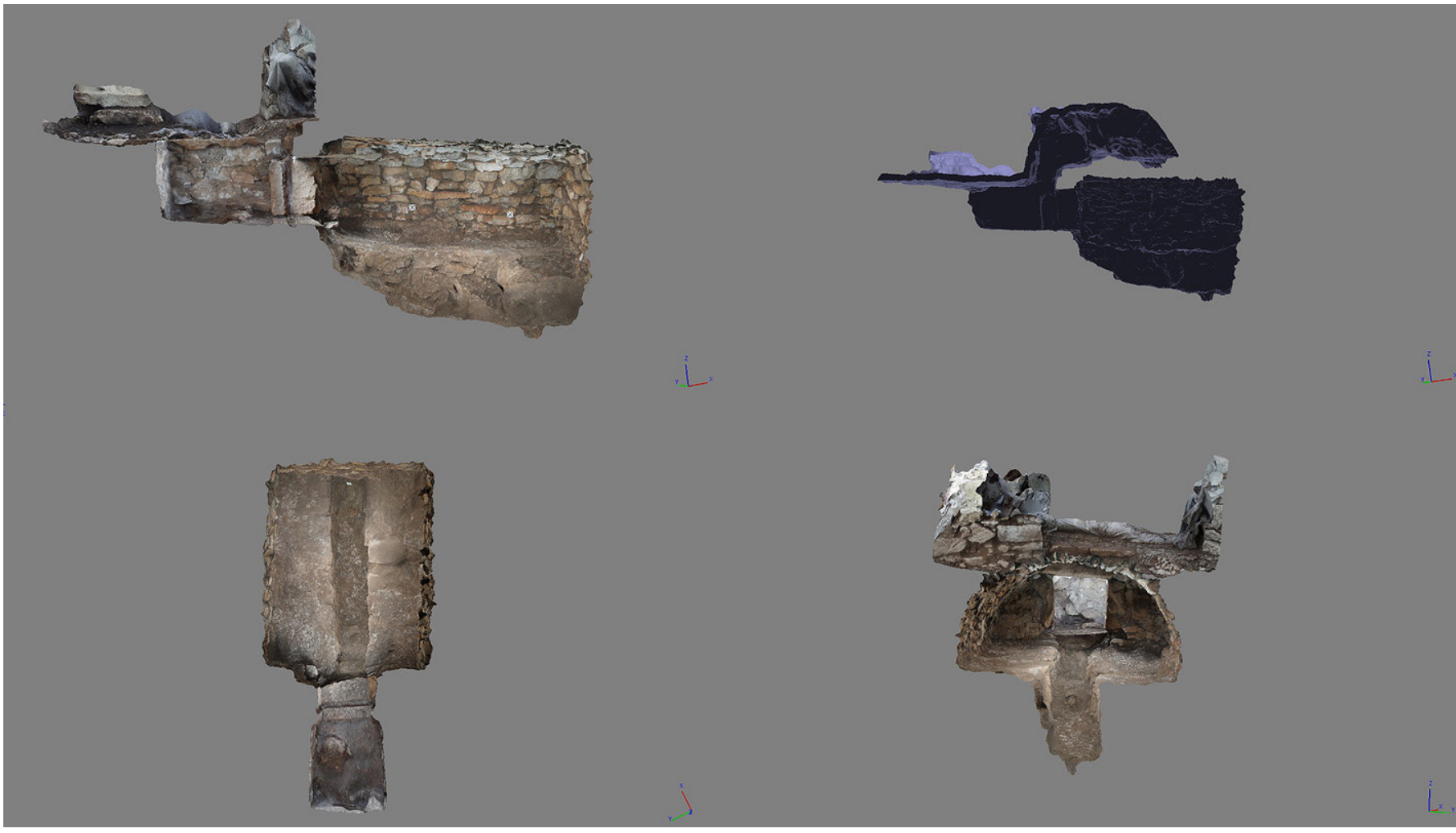

Figure 8. Orthophoto extraction (Archive of the Velić project, made by: M. Vuković).

Figure 9. Understructure view of the excavated building in the vicinity of Velić (Archive of the Velić project, made by: M. Vuković).

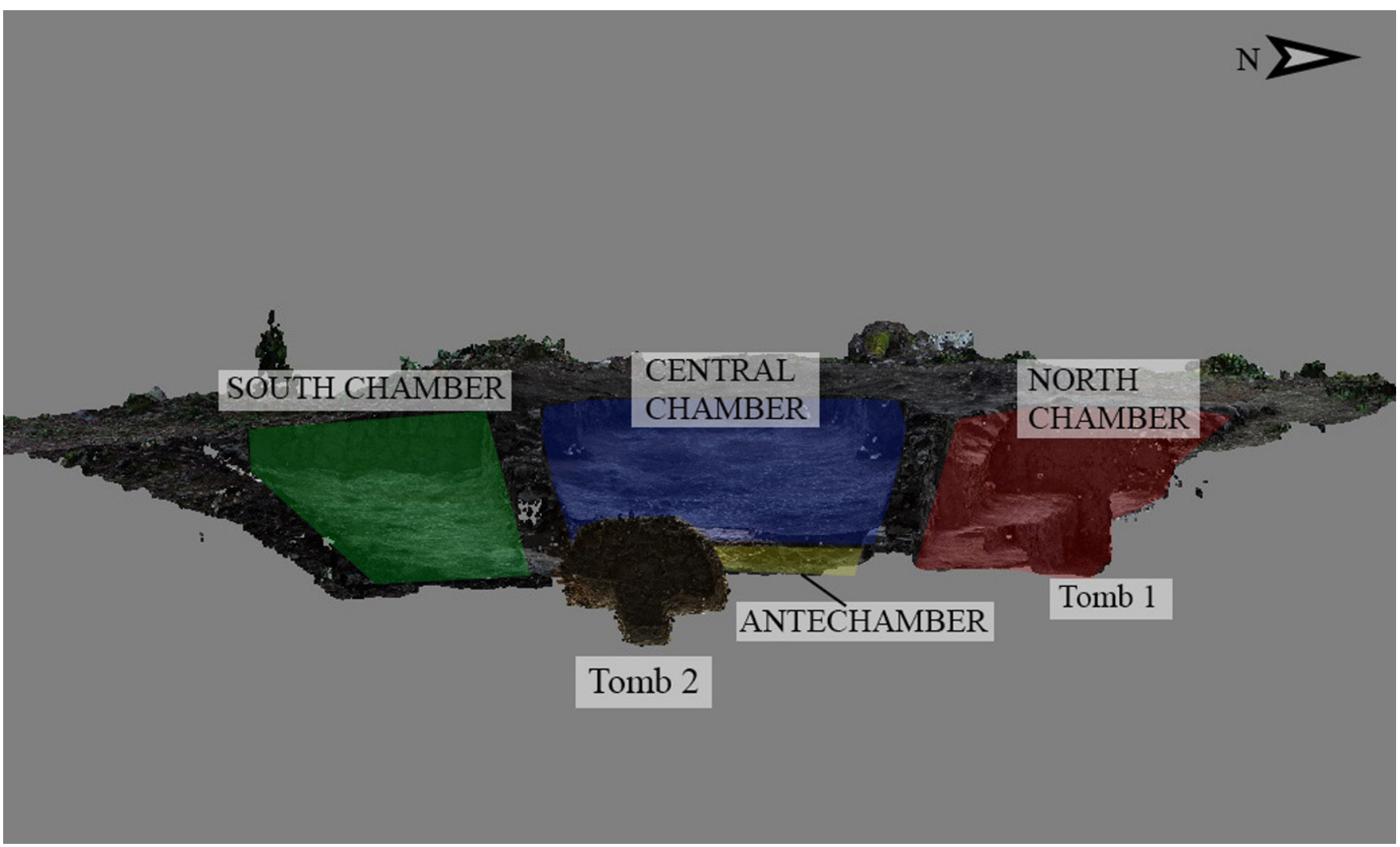




\section{Conclusion and further work}

This paper presented the difficulties and the solutions that came across during the documentation process of the Early Christian memorial chapel in Velić and especially of the barrel-vaulted tomb (Tomb 2). Although documenting excellently preserved and intact Tomb 2 has proved challenging, the team managed to acquire a complete georeferenced image-based model which was then successfully merged with the models from the previous excavation seasons and thus completing the general view of this Early Christian memorial chapel (Fig. 1). While analyzing the merged data, two things became apparent. With the addition of Tomb 2 at the northern side of the building, the southern side of the apsed building shows a lack of understructures (Fig. 9), and the second obvious conclusion was that there is enough space for another tomb. It is tempting to expect that further research could yield more understructures (probably barrel-vaulted tombs) whose entrances are concealed better underneath the plastered floor of the southern side of the apsed building. Examples of barrel-vaulted tombs underneath plastered floors are known in other sites as well. Naturally, it is necessary to ask oneself whether one can expect more than one privileged grave beneath the Early Christian memorial chapel. As we previously concluded there is enough space for another barrel-vaulted tomb between Tombs 1 and 2 . It is interesting that in the entrance hall, north of the entrance to the central room of the building and the entrance to Tomb 2, a fragment of an architectural element (VEL 19 PN 12) reminiscent of the door jambs of Tombs 1 and 2 was documented in 2019. It was documented in the area where the floor in the entrance hall has not been preserved, and where there was a breach in the substructure of the floor. By analyzing the complete georeferenced image-based model of the Early Christian memoria, the location of the possible door jamb and the destroyed floor seem to suggest a possible entrance to an additional tomb next to Tomb 2. Given the documented traces of the devastation of the Tomb 1 and the scattered bones in the central chamber with the apse, it is possible that that is a devastated entrance to another tomb. The question of the possible existence of additional tombs under the Early Christian memorial chapel in Velić could be answered by future archaeological excavations.

\section{Acknowledgement}

We are grateful to The volunteer fire department of Trilj (DVD Trilj), and especially Commander Mladen Klarić, for their technical assistance during the opening of the Tomb 2. 


\section{References}

Agisoft LLC, 2019. Agisoft Metashape User Manual: Professional Edition, Version 1.5.

Bubić, V. 2015. Terenski pregled lokaliteta kod Velića, In: I. Alduk and D. Tončinić (eds.), Istraživanja u Imotskoj krajini, Izdanja Hrvatskog arheološkog društva 29, Zagreb, 91-101.

Bubić, V. 2016. Tipologija i topografija kasnoantičkih grobova u arheološkom krajoliku srednje Dalmacije, Unpublished PhD Thesis, University of Zagreb, Zagreb.

Bužanić, D., Dunjko, D., Glavinić, B., Ivak, K., Manhard, A., Šekrst, J. and Vidović, I. 2017. Mapiranje arheološkog nalazišta Velić 2014. - 2016. godine, Fragmenti - časopis studenata Odsjeka za arheologiju 5, Zagreb, 45-62.

Bužanić, D., Glavinić, B., Ivak, K., Šekrst, J. and Vidović, I. 2018. Mapiranje arheološkog lokaliteta Velić u kontekstu povijesnih cestovnih komunikacija, Fragmenti - časopis studenata Odsjeka za arheologiju 6, Zagreb, 33-46.

Gonizzi Barsanti, S., Remondino, F. and Visintini, D. 2012. Photogrammetry and Laser Scanning for Archaeological Site 3D Modelling - Some Critical Issues, In: V. Roberto and L. Fozzati (eds.), Proceedings of the 2nd Workshop on 'The New Technologies for Aquileia', Aquileia, B1-B10.

Novak, M. and Carić, M. 2019. Bioarheološka analiza ljudskih koštanih ostataka s nalazišta Velić, Specialist report, Zagreb.

Šlaus, M., Novak, M., Vyroubal, V., Bedić, Ž. and Perić Peručić, J. 2013. Rezultati antropološke analize ljudskog osteološkog materijala s nalazišta Velić kraj Trilja, Specialist report, Zagreb.
Šlaus, M., Vyroubal, V., Bedić Ž. and Adamić, A. 2018. Rezultati antropološke analize osteološkog materijala $s$ nalazišta Velić. Specialist report, Zagreb.

Tončinić, D. 2020. Nepoznato arheološko nalazište Velić kod Trilja, In: M. Sanader, D. Tončinić, I. Kaić and V. Matijević (eds.), Zbornik I. skupa hrvatske ranokršćanske arheologije (HRRANA), Zagreb, 367-381.

Tončinić, D. and Demicheli, D. 2013. Velić, Hrvatski arheološki godišnjak 10, Zagreb, 622-624.

Tončinić, D., Demicheli, D., Bužanić, D., Dunjko, D., Glavinić, B. and Manhard, A. 2014. Velić, Hrvatski arheološki godišnjak 11, Zagreb, 668-669.

Tončinić, D., Sanader, M., Vuković, M., Bužanić, D., Dunjko, D., Glavinić, B. and Manhard, A. 2015. Velić, Hrvatski arheološki godišnjak 12, Zagreb, 798-800.

Tončinić, D., Sanader, M., Vuković, M., Bužanić, D., Glavinić, B., Ivak, K., Šekrst, J. and Vidović, I. 2016. Velić, Hrvatski arheološki godišnjak 13, Zagreb, in press.

Tončinić, D., Sanader, M., Matijević, V., Vuković, M. 2017. Velić, Hrvatski arheološki godišnjak 14, Zagreb, in press.

Tončinić, D., Sanader, M., Matijević, V., Vuković, M. 2018. Velić, Hrvatski arheološki godišnjak 15, Zagreb, in press.

Tončinić, D., Sanader, M., Matijević, V., Bužanić, D., Vuković, M. 2019. Velić, Hrvatski arheološki godišnjak 16, Zagreb, in press. 